\title{
Early administration of indomethacin to preterm infants
}

\author{
J M RENNIE, J DOYLE, AND R W I COOKE \\ Regional Neonatal Intensive Care Unit, Department of Child Health, University of Liverpool, Liverpool \\ Maternity Hospital
}

SUMMARY Indomethacin $(0.2 \mathrm{mg} / \mathrm{kg})$ or saline was given intravenously during the first 24 hours to 50 preterm infants in a double blind controlled trial. Eight of the control group later required treatment with indomethacin for clinical signs of left to right shunt, but only one in the treatment group $(p=0 \cdot 03)$. Treatment with indomethacin prolonged bleeding time, raised serum creatinine concentrations, and was associated with gastrointestinal haemorrhage in seven infants. Five of these had a serum indomethacin concentration greater than $1.0 \mu \mathrm{g} / \mathrm{ml}$. There was a significant reduction of the stable metabolite of prostacyclin, 6-ketoprostaglandin $\mathrm{F}_{1 \alpha}$, commencing six hours after treatment and lasting for four days. There was no significant difference in the incidence of intraventricular haemorrhage, days of treatment with oxygen or ventilation, or mortality between the two groups.

Since the introduction of indomethacin into neonatal practice for functional closure of the patent ductus arteriosus, this drug has become widely used. ${ }^{1}$ Several double blind controlled trials have confirmed that it is effective in altering clinical signs of left to right shunt in low birthweight infants, ${ }^{2-4}$ although the debate continues regarding optimal timing, route, and dosage. ${ }^{5}$

Prostaglandins are considered an important factor in maintaining the patency of the preterm ductus. ${ }^{6}$ Prostaglandin E is a more potent dilator of the isolated ductus preparation than prostacyclin, ${ }^{7}$ although the lamb ductus can be shown to generate only prostacyclin from the precursors. ${ }^{8}$ The stable metabolite of prostacyclin, 6-ketoprostaglandin $F_{1 \alpha}$, is the major product of ductus homogenate. ${ }^{9}$ Prostacyclin may thus be of more importance than prostaglandin $\mathrm{E}$ in vivo.

Indomethacin is a potent but reversible inhibitor of cyclo-oxygenase, the enzyme that catalyses oxygenation of endoperoxides to their prostaglandin products. ${ }^{10}$ Timing of onset of inhibition is not well defined. Reduction of urinary prostaglandin E metabolite in five healthy adults was $59-95 \%$ at 24 hours. " Similar effects have been seen in neonates, with a resurgence of urinary prostaglandin $\mathrm{E}$ metabolite after six days corresponding with clinical relapse in six of a group of eight infants with patent ductus arteriosus. ${ }^{12}$ Suppression of urinary 6-keto- prostaglandin $\mathrm{F}_{1 \alpha}$ in preterm infants seven days after treatment with indomethacin has been shown. ${ }^{13}$ The clinical response and the in vitro effects of indomethacin suggest a more rapid onset, ${ }^{14}$ and there is controversy regarding the relevance of estimation of urinary prostaglandin as an index of systemic production. ${ }^{15}$

This study was designed to temporally relate plasma 6-ketoprostaglandin $F_{1 \alpha}$, indomethacin concentrations, and clinical response in a group of low birthweight infants receiving intensive care.

\section{Patients and methods}

Patient population. The study group consisted of 50 preterm infants with birth weight less than $1750 \mathrm{~g}$ admitted within the first 24 hours of life to the Liverpool Regional Neonatal Intensive Care Unit between May 1984 and June 1985. The study had prior approval from the local ethical committee. Real time ultrasound scanning of the brain was performed as soon as possible after admission, ${ }^{16}$ and infants without intraventricular haemorrhage who had passed urine were entered into the trial.

Treatment was $0.2 \mathrm{ml} / \mathrm{kg}$ of 'trial solution' given intravenously: this was either freshly prepared from a vial containing $1 \mathrm{mg}$ lyophilised indomethacin to which $1 \mathrm{ml}$ of normal saline was added or an identical volume of saline. The solution was pre- 
pared by a member of the nursing staff, the remaining staff being ignorant regarding the nature of the solution. A total of three doses were administered at 24 hourly intervals unless treatment was stopped by the clinical team.

Information regarding the infant's history, results of routine laboratory investigations, details of ventilator settings, and blood gas analysis in the treatment of respiratory distress syndrome were recorded prospectively during admission. Ultrasound scanning was carried out daily for the first four days and weekly thereafter, with additional scans at times of acute deterioration. Estimation of bleeding time by a capillary micromethod ${ }^{17}$ was performed before and two hours after the first dose of trial solution.

Measurement of 6-ketoprostaglandin $F_{1 \alpha}$. Samples of blood were collected before and at half, two, six to eight, 24,48 , and 72 hours after the administration of trial solution and at various times over the first two weeks. For estimation of prostaglandin 0.5 $\mathrm{ml}$ of blood was collected either from an indwelling arterial line or by direct venepuncture into ice cold, indomethacin coated, edetic acid test tubes and spun down immediately on ice at $3000 \mathrm{~g}$ for 15 minutes to prepare platelet poor plasma. This was separated and stored at $-20^{\circ} \mathrm{C}$ until assay within three months. Samples showing evidence of haemolysis were discarded.

Assay was by radioimmunoassay of $100 \mu \mathrm{l}$ unextracted plasma. All assays were performed in duplicate in a medium of plasma free of prostaglandin. The tracer was iodinated 6-ketoprostaglandin $F_{1 \alpha}$, the antibody raised in rabbits (Seragen Ltd), and separation of bound from free was using a double antibody technique. The smallest quantity detectable was $25 \mathrm{pg} / \mathrm{ml}$; intra-assay coefficient of variation was $6 \%$ and interassay coefficient of variation $16 \%$. Cross sensitivity to prostaglandins $\mathrm{A}, \mathrm{D}, \mathrm{E}, \mathrm{F}_{1 \alpha}, \mathrm{F}_{2 \alpha}$, and 13,14 dihydro 6-ketoprostaglandin $F_{1 \alpha}$ was less than $1 \%$.

Measurement of indomethacin. Estimation of indomethacin from blood collected into plain tubes simultaneously with the prostaglandin samples was performed using high pressure liquid chromatography. ${ }^{18}$ All reagents were analytical grade (British Drug Houses Ltd) and the chromatography was carried out using a $10 \mu \mathrm{m}$ radial-Pak $C_{18}$ reverse phase column (Waters Associates Ltd) and radial compression module (Waters Model RCM-100). The pump was Specta-Physics $8500 \mathrm{~A}$ with variable wavelength detector and automatic integrator. The following chromatography conditions were used: mobile phase acetonitrile: water 45:55 vol:vol containing $0.5 \%$ acetic acid, flow rate $2 \mathrm{ml} / \mathrm{min}$, wavelength $260 \mu \mathrm{m}$, detector range 0.02 absorbed unit full scale (AUFS), injection volume $100 \mu \mathrm{l}$, and temperature ambient. Plasma samples were extracted with ether, inclusion of $0.1 \mathrm{ml}$ of $10 \mu \mathrm{g} / \mathrm{ml}^{-1}$ phenylbutazone solution (Geigy) was made into all samples as an internal control. The retention times for indomethacin and phenylbutazone were seven and 12 minutes, respectively.

The response of peak height was linear between $0 \cdot 1$ and $1 \mathrm{mg} / \mathrm{ml}$. Calculation of unknowns was from the linear graph generated from extraction of samples prepared from drug free plasma to which a known mass of indomethacin was added. Recovery of indomethacin after extraction was $87 \%$, and coefficient of variation for the assay had a mean value of $11 \%+5 \%$. The lower limit of detection was $0 \cdot 1 \mu \mathrm{g} / \mathrm{ml}^{-1}$.

Statistical methods. Analysis of data was by use of $t$ test for quantitative information, including birth weight and alveolar arterial oxygen gradients. Prostaglandin concentrations between groups were compared using the Mann-Whitney U test, and categorical variables compared using the $\chi^{2}$ test or Fisher's exact test as appropriate.

\section{Results}

The groups of infants were well matched for birth weight, sex distribution, gestational age, mode of delivery, numbers of inborn babies, and incidence of asphyxia (Table 1). A similar number in each group required ventilation for respiratory distress syndrome, and the ventilatory support required at 24 hours was not significantly different (Table 2). Numbers of infants receiving pancuronium and developing pneumothorax and hypercarbia were comparable, and although both infants who developed chronic lung disease were in the placebo group the duration of treatment with oxygen and ventilator was not significantly different. Alveolararterial oxygen gradients were calculated ${ }^{19}$ for three occasions on the first three days of life where results

Table 1 Birth characteristics in study infants

\begin{tabular}{lcc}
\hline & \multicolumn{2}{c}{ Treatment gooup } \\
\cline { 2 - 3 } & $\begin{array}{l}\text { Indomethacin } \\
(n=24)\end{array}$ & $\begin{array}{c}\text { Placebo } \\
(n=26)\end{array}$ \\
\hline Birth weight (g) (mean (SD)) & $1214(323)$ & $1330(326)$ \\
Gestational age (weeks) (mean (SD)) & $28(2 \cdot 3)$ & $29(2 \cdot 0)$ \\
Sex (M:F) & $13: 11$ & $18: 8$ \\
Premature rupture of membranes & 2 & 0 \\
Inborn & 14 & 17 \\
Apgar score <3 at one minute & 7 & 3 \\
Caesarian section delivery & 10 & 8 \\
\hline
\end{tabular}


Table 2 Respiratory treatment and complications in infants with respiratory distress syndrome

\begin{tabular}{|c|c|c|c|}
\hline & \multicolumn{2}{|c|}{ Treatment group } & \\
\hline & $\begin{array}{l}\text { Indomethacin } \\
(n=24)\end{array}$ & $\begin{array}{l}\text { Placebo } \\
(n=26)\end{array}$ & \\
\hline $\begin{array}{l}\text { Respiratory distress syndrome } \\
24 \text { hour ventilator settings }\end{array}$ & 17 & 18 & NS \\
\hline $\begin{array}{l}\text { Peak inspiratory pressure } \\
\left(\mathrm{cm} \mathrm{H}_{2} \mathrm{O}\right) \text { (mean (SD)) }\end{array}$ & $19(4)$ & $21(5)$ & NS \\
\hline $\begin{array}{l}\text { Rate }(\text { cycles } / \min ) \\
(\text { mean }(S D))\end{array}$ & $37(29)$ & $50(26)$ & NS \\
\hline $\begin{array}{l}\text { Fractional inspiratory oxygen } \\
\text { (mean (SD)) }\end{array}$ & $0.67(0.26)$ & $(1.73(0.22)$ & NS \\
\hline Pancuronium treatment & 5 & 10 & NS \\
\hline Pneumothorax & 4 & 7 & NS \\
\hline $\begin{array}{l}\text { Hypercarbia (arterial carbon } \\
\text { dioxide tension }>8 \mathrm{KPa} \text { ) }\end{array}$ & 5 & 6 & NS \\
\hline Bronchopulmonary dysplasia & () & 2 & NS \\
\hline Days of ventilation (mean) & $4 \cdot 18$ & $4 \cdot 5$ & NS \\
\hline Days of oxygen (median) & 10 & 14 & NS \\
\hline $\begin{array}{l}\text { Alveolar arterial oxygen gradi } \\
(\mathrm{mmHg}) \text { (mean (SD)) }\end{array}$ & & & \\
\hline Day 1 & $454(17.3)$ & $481(196)$ & NS \\
\hline Day 2 & $403(184)$ & $431(177)$ & NS \\
\hline Day 3 & 293 (146) & $377(1+(0)$ & $0 \cdot 02$ \\
\hline
\end{tabular}

were available, and there was a significant reduction on the third day of life in the treated group.

Treatment with indomethacin prolonged bleeding time (Table 3), and seven treated infants were in the group of eight infants who had an indomethacin concentration greater than $1.0 \mu \mathrm{g} / \mathrm{ml}$ at any time during the first three days (Fig. 1). Indomethacin
Table 3 Bleeding times in study infants

\begin{tabular}{|c|c|c|c|}
\hline & Pretreatment & Post & atment \\
\hline \multicolumn{4}{|c|}{ Indomethacin $(n=14)$ : } \\
\hline Time $(\mathrm{min})$ & $2 \cdot 7$ & $5 \cdot 53$ & $\mathrm{p}<0 \cdot(x) 1$ \\
\hline Volume (ml) & 0.03 & $0 \cdot 11$ & $p=0.05$ \\
\hline \multicolumn{4}{|l|}{ Placebo $(n=15)$} \\
\hline Time $(\mathrm{min})$ & $2 \cdot 7$ & $3 \cdot 02$ & NS \\
\hline Volume $(\mathrm{ml})$ & (1). 12 & $0 \cdot 11$ & NS \\
\hline
\end{tabular}

concentrations showed a wide variation. A reduction in urine output was noted in three of the treated group and two of the placebo group. The peak serum creatinine concentration was higher in those infants who received indomethacin $(p=0.008)$ (Table 4).

No infant had his treatment stopped on clinical grounds, but eight infants in the placebo group and one in the treatment group were re-treated by the clinical team for clinical signs considered to be those of an appreciable ductal shunt, including full pulses, ductal murmur, or increasing ventilatory requirements. No infant required surgical ligation.

6-Ketoprostaglandin $\mathrm{F}_{1 \alpha}$ concentrations were reduced by treatment with indomethacin with a significant reduction compared with the pretreatment value and with the control group by six hours. Individual concentrations are shown in Figures 2 and 3 . In 11 of the 15 treated infants who had

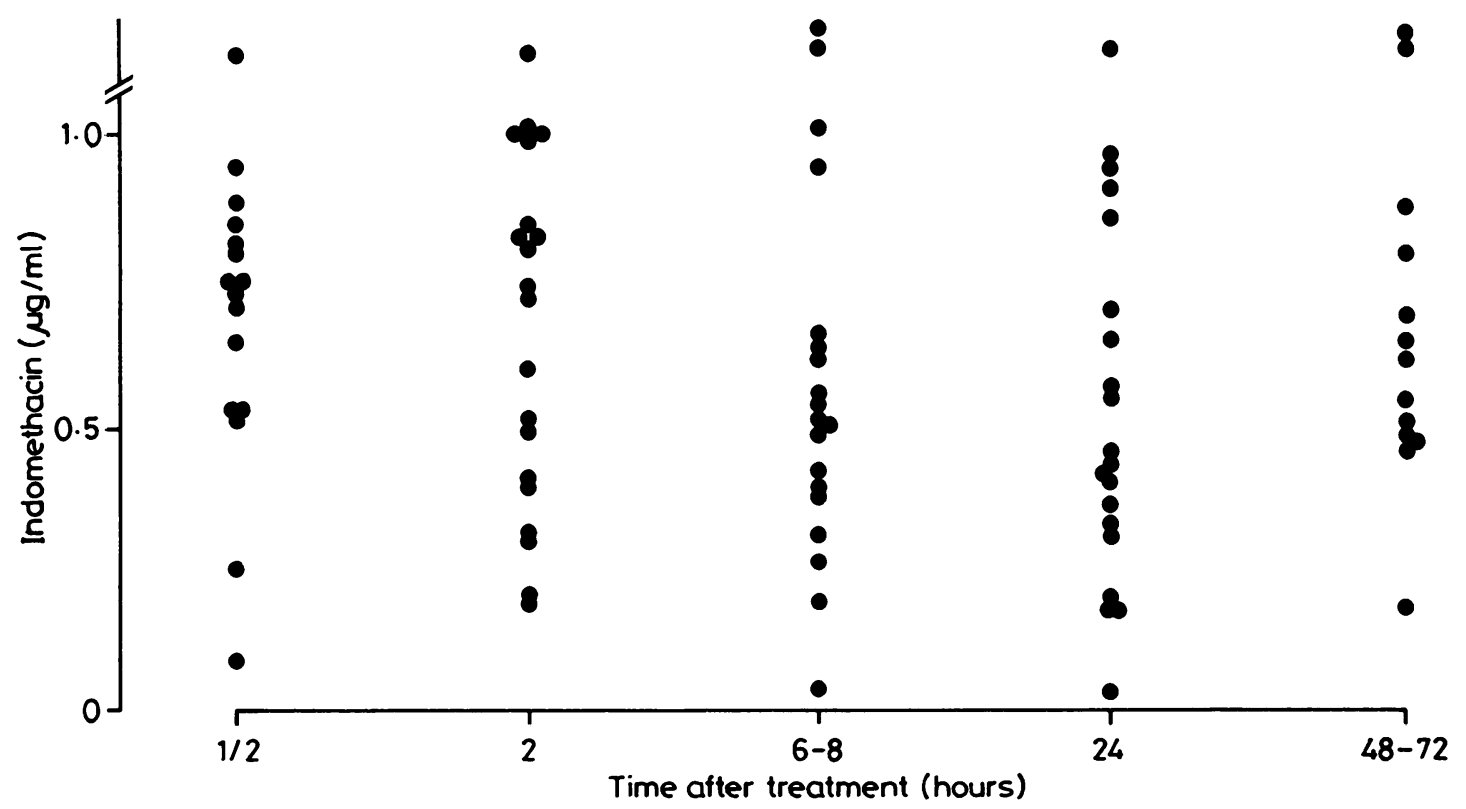

Fig. 1 Plasma concentrations of indomethacin at intervals after treatment. 
Table 4 Clinical course and laboratory results in study infants

\begin{tabular}{|c|c|c|c|}
\hline & \multicolumn{2}{|c|}{ Treatment group } & \\
\hline & $\begin{array}{l}\text { Indomethacin } \\
(n=24)\end{array}$ & $\begin{array}{l}\text { Placebo } \\
(n=26)\end{array}$ & \\
\hline Death & 5 & 8 & NS \\
\hline Intraventricular haemorrhage & 10 & 9 & NS \\
\hline Gastrointestinal bleed & 7 & 0 & $\mathrm{p}=0 \cdot 01^{*}$ \\
\hline Renal impairment & 3 & 2 & NS \\
\hline $\begin{array}{l}\text { Peak serum creatinine } \\
\quad(\mathrm{mmol} / \mathrm{l})(\text { mean }(\mathrm{SD}))\end{array}$ & $121(34)$ & $96(19)$ & $p=0 \cdot(008 \dagger$ \\
\hline $\begin{array}{l}\text { Serum sodium }(\mathrm{mmol} / \mathrm{l}) \\
(\text { mean }(\mathrm{SD})):\end{array}$ & & & \\
\hline Day 1 & $136(3)$ & $136(2 \cdot 5)$ & NS \\
\hline Day 2 & $137(6)$ & $138(4)$ & NS \\
\hline $\begin{array}{l}\text { Retreatment for patent } \\
\text { ductus arteriosus }\end{array}$ & 1 & 8 & $\mathrm{p}=0.05^{*}$ \\
\hline
\end{tabular}

estimations of prostaglandin performed the concentration was less than $50 \mathrm{pg} / \mathrm{ml}$ between the second and fifth day of life; two had high concentrations throughout the study (one died), there was one early death, and no late samples were obtained from a fourth infant. In 11 of 15 , however, a significant rise was shown after the sixth day $(\mathrm{p}<0 \cdot 001)$ (Table 5).
Table 5 Rise of 6-ketoprostaglandin $F_{l \alpha}$ concentrations after inhibition by treatment with indomethacin

\begin{tabular}{ll}
\hline $\begin{array}{l}\text { Plasma concentration }(\mathrm{pg} / \mathrm{ml}) \\
\text { days } 2-5\end{array}$ & $\begin{array}{l}\text { Plasma concentration }(\mathrm{pg} / \mathrm{ml}) \\
\text { days } 6-10\end{array}$ \\
\hline$<25$ & 59 \\
$<25$ & 57 \\
$<25$ & 53 \\
44 & 145 \\
41 & 137 \\
$<25$ & 27 \\
38 & 60 \\
$<25$ & 32 \\
26 & 97 \\
$<25$ & 30 \\
$<25$ & 27 \\
\hline $\mathrm{p}=0.001$ by Mann-Whitney U test.
\end{tabular}

\section{Discussion}

Treatment with indomethacin achieved a significant in vivo inhibition of prostacyclin synthesis in this group of low birthweight infants, and early treatment was associated with a prevention of ductal signs warranting intervention in the neonatal period. The reduction in duration of treatment with ventilator or oxygen by early treatment shown in some

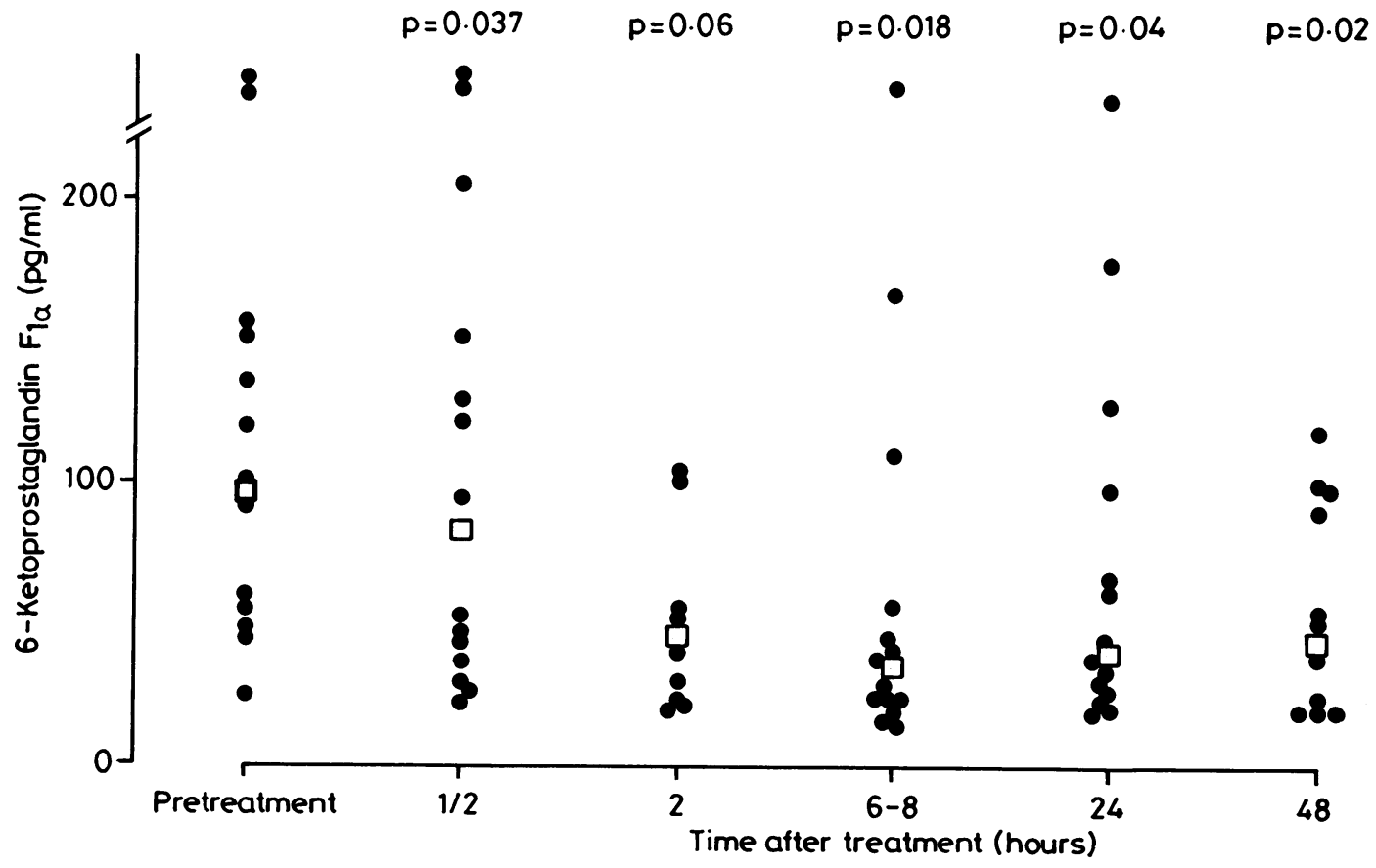

Fig. 2 Concentrations of 6-ketoprostaglandin $F_{l \alpha}$ in treated group $(\square=$ median $)$. 


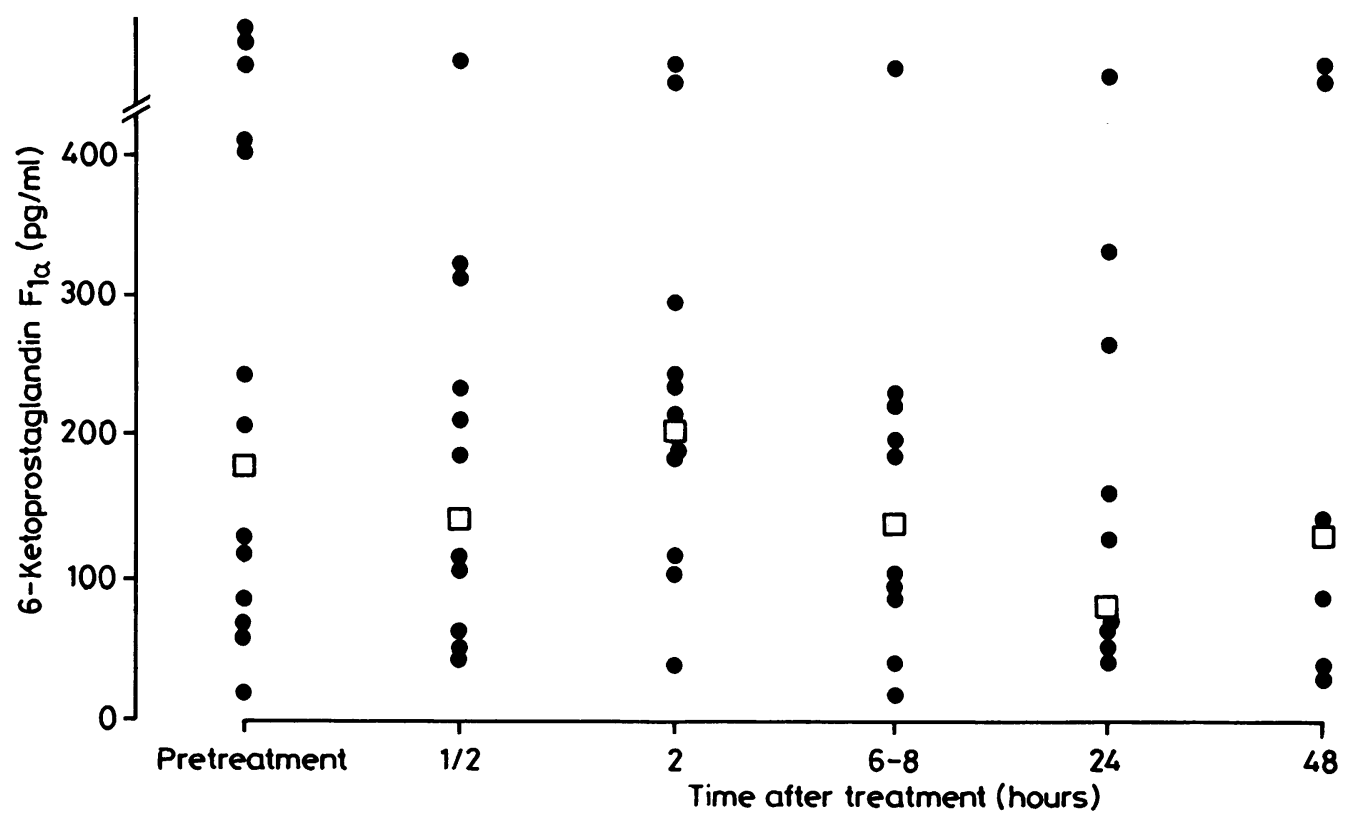

Fig. 3 Concentrations of 6-ketoprostaglandin $F_{l \alpha}$ in placebo group $(\square=$ median $)$.

series $^{2021}$ was not confirmed, although the reduction of alveolar arterial oxygen gradient on the third day may have been due to a reduction of pulmonary oedema by early ductal closure.

The effect of treatment with indomethacin on prostacyclin synthesis has been suggested to be dose related in adults, ${ }^{22}{ }^{11}$ but the current neonatal dose is 10 -fold less than that used in the original study ${ }^{23}$ and that administered to adult patients. Plasma concentrations after dosing showed a wide variation similar to previous results, again making precise recommendations for dosage difficult. ${ }^{24}$ The timing of reduction of prostaglandin synthesis is in keeping with the clinical response and provides further indirect evidence that prostaglandins are a factor in the control of ductal tone. A fall in plasma prostaglandin $\mathrm{E}$ concentrations in two of three infants six hours after treatment with indomethacin has been shown. ${ }^{25}$ This work does not support the concept that a threshold concentration of indomethacin is needed for either clinical effect or inhibition of prostaglandin synthesis.

The large number of infants suffering gastrointestinal haemorrhage included significantly more of the infants with high indomethacin concentrations.

Indomethacin exerts a potent and generalised effect on cyclo-oxygenase, that from platelets appearing particularly sensitive ${ }^{26} \mathrm{~A}$ prolongation of bleeding time has been documented ${ }^{27}$ and is an undesirable effect resulting from inhibition of platelet thromboxane synthesis. Complications due to disturbances of haemostasis are common in the newborn, but in this group there was no excess incidence of intraventricular haemorrhage among treated infants. Other workers have observed that there has been no excess of intraventricular haemorrhage in infants receiving indomethacin for patent ductus and that indomethacin did not cause extension of intraventricular haemorrhage. ${ }^{28}$ The adverse effects on platelet function are possibly balanced in the ill infant by the concomitant removal of the vasodilating influence that prostacyclin exerts on the cerebral circulation. ${ }^{29}$ Loss of this effect on the renal microvasculature and reduction of renal blood flow almost certainly accounts for the rise of creatinine concentrations. ${ }^{30}$

The observation that the duration of inhibition is of the order of four days is an important one and has clinical implications as the relapse rate is often high after treatment with indomethacin. ${ }^{31}$ Not all preterm infants will develop an appreciable left to right shunt, and we would not agree that 'prophylactic' treatment is completely safe. ${ }^{5}$ Perhaps the conclusion to be drawn from this study is that the way to use indomethacin in the preterm infant is to treat as soon as he develops signs with a small dose of intravenous indomethacin and to continue it daily for as long as a week. 
We thank the medical and nursing staff of the Neonatal Intensive Care Unit, Liverpool Maternity Hospital, for clinical care of the patients, Merck Sharpe and Dohme for the cooperation in supplying the indomethacin, Mr T Gibson for performing volume estimations on bleeding time blood, Mr T Nunn for pharmacy coordination, and Mrs Sandra Longworth for typing the manuscript.

Dr Rennie was financially supported by the Mersey Regional Area Health Authority.

\section{References}

' Heymann MA, Rudolph AM, Silverman NH. Closure of the ductus arteriosus in premature infants by inhibition of prostaglandin synthesis. $N$ Engl J Med 1976;295:530-3.

2 Rudd P, Montanez P, Hallidie-Smith K. Silverman M. Indomethacin treatment for PDA in VLBWI: double blind trial. Arch Dis Child 1983;58:267-70.

3 Yeh TF, Luken JA, Thalji A, Raval D, Carr I, Pildes RS. Intravenous indomethacin therapy in premature infants with PDA. J Pediatr 1981;98:131-5.

${ }^{4}$ Yanagi RM, Wilson A, Newfield EA, Aziz KU, Hunt CE. Indomethacin treatment for symptomatic duct: a double-blind controlled study. Pediatrics 1981;67:647-52.

5 Mahony L, Caldwell RL, Girod DA. et al. Indomethacin therapy on the first day of life in infants with very low birthweight. J Pediatr 1985;106:801-5.

${ }^{6}$ Coceani F, Olley PM, Lock JE. Prostaglandins, ductus arteriosus, pulmonary circulation: current concepts and clinical potential. Eur J Clin Pharmacol 1980;18:75-81.

7 Clyman RI, Mauray F, Raman C, Rudolph A. PGE 2 is a more potent vasodilator of the lamb ductus than $\mathrm{PGI}_{2}$ or $6 \mathrm{Keto} \mathrm{PGF}_{1}$ alpha. Prostaglandins 1978;16:259.

${ }^{8}$ Skidgel RA, Friedman WF, Printz MP. Prostaglandin biosynthetic activities of isolated lamb ductus other blood vessels and lung. Pediatr Res 1984;18:12-19.

${ }^{9}$ Pace-Asciak CR, Rangaraj G. The $6 \mathrm{Keto} \mathrm{PGFI}_{1}$ alpha pathway in the lamb ductus arteriosus. ${ }^{1}$ Biochim Biophys Acta 1977; 486:583-5.

${ }^{10}$ Metz SA. Anti-inflammatory agents as inhibitors of prostaglandin synthesis in man. Med Clin North Am 1981;65:713-57.

1 Rane A, Oelz O, Frolich JC, et al. Relation between plasma concentration of indomethacin and its effect on prostaglandin synthesis and platelet aggregation in man. Clin Pharmacol Ther 1978;23:658-68.

12 Seyberth HW, Muller H, Wille L. Pluckthon H, Wolf D, Sulmer HE. Recovery of prostaglandin production associated with reopening of the ductus arteriosus after indomethacin treatment in preterm infants with respiratory distress syndrome. Pediatr Pharmacol (New York) 1982:2:127-41.

${ }^{13}$ Seyberth HW, Muller H, Ulmer HE, Willie L. Urinary excretion rates of 6 Keto $P_{1} F_{1}$ alpha in preterm infants recovering from respiratory distress with and without patent ductus arteriosus. Pediatr Res 1984;18:520-4.

14 Rome LH, Lands WEM. Structural requirements for time dependent inhibition of prostaglandin biosynthesis by antiinflammatory drugs. Proc Natl Acad Sci USA 1975;72:4803-5.
${ }^{15}$ Rosenkranz B, Kitajima W, Frolich JC. Relevance of urinary 6 Ketoprostaglandin $F_{1}$ alpha determinations. Kidney Int 1981; 19:755-9.

${ }^{16}$ Cooke RWI. Ultrasound examination of neonatal heads. Lancet, 1979:ii:38.

17 Rennie JM, Gibson T, Cooke RWI. Micromethod for bleeding time in the newborn. Arch Dis Child 1985;60:51-3.

18 Mehta AC. Calvert RT. An improved high performance liquid chromatographic technique for monitoring indomethacin in neonates. Ther Drug Monit 1983;5:143-5.

19 Thiebault ON, Gregory GA. Neonatal pulmonary care. California: Addison Wesley, 1979.

20) Kaapa P. Lanning P, Koivisto M. Early closure of patent ductus arteriosus with indomethacin in preterm infants with idiopathic respiratory distress syndrome. Acta Pediatr Scand 1983;72: 179-184.

21 Mahony L, Carnero V, Brett C, Heymann MA, Clyman R. Prophylactic indomethacin therapy for patent ductus arteriosus in very low birthweight infants. $N$ Engl J Med 1982;306:506-10.

22 Cockbill SR, Heptinstall S, Taylor PM. A comparison of the abilities of acetylsalicylic acid, flurbiprofen and indomethacin to inhibit the release reaction and prostaglandin synthesis in human blood platelets. Br J Pharmacol 1979;67:73-8.

23 Friedman WF, Hirschklan MJ. Printz MP. Pitlick PT, Kirkpatrick SE. Pharmacologic closure of patent ductus arteriosus in the premature infant. $N$ Engl J Med 1976;295:526-539.

${ }^{24}$ Brash AR, Hickey DE, Graham TP. Stahlman MT, Oates JA, Cotton RB. Pharmacokinetics of indomethacin in the neonate. $N$ Engl J Med 1981;305:67-72.

25 Lucas A, Mitchell MD. Plasma prostaglandins in preterm neonates before and after treatment for PDA. Lancet 1978;ii: $130-2$.

${ }^{26}$ Kocsis JJ, Hernandovich J, Silver MJ, Smith JB, Ingerman C. Duration and inhibition of platelet prostaglandin formation and aggregation by ingested aspirin or indomethacin. Prostaglandins 1973;3:141-4.

27 Corazza MS, Davis RF, Merritt TA, Bejar R, Cvetnic W. Prolonged bleeding time in preterm infants receiving in domethacin for PDA. J Pediatr 1984;105:292-6.

${ }^{28}$ Maher P, Lane B, Ballard R, Piecuch R, Clyman RI. Does indomethacin cause extension of intracranial hacmorrhages: a preliminary study. Pediatrics 1985;75:497-500.

${ }^{29}$ Pickard JD. Role of prostaglandins and arachidonic acid derivatives in the coupling of cbf to cerebral metabolism. $J$ Cereb Blood Flow Metab 1981;1:361-84.

30) Harron R, Zipser R, Fichmann M. Renal function and vascular regulation. Med Clin North Am 1981;65:891-907.

31 Mellander M, Leheup B, Lindstrom DP, et al. Recurrence of symptomatic PDA in premature infants treated with indomethacin. J Pediatr 1984;105:138-43.

Correspondence to Dr J M Rennie, Department of Paediatrics, Level 8, Addenbrooke's Hospital, Hills Road, Cambridge CB2 2QQ.

Received 2 December 1985 